\title{
Reduced fish diversity despite increased fish biomass in a Gulf of California Marine Protected Area
}

\author{
Georgina Ramírez-Ortiz ${ }^{\text {Corresp., } 1}{ }^{\text {, Héctor Reyes-Bonilla }}{ }^{2}$, Eduardo F. Balart ${ }^{1}$, Damien Olivier ${ }^{2,3}$, Leonardo Huato- \\ Soberanis ${ }^{1}$, Fiorenza Micheli ${ }^{4}$, Graham J. Edgar ${ }^{5}$ \\ 1 Programa de Ecología Pesquera, Centro de Investigaciones Biológicas del Noroeste S.C., La Paz, Baja California Sur, México \\ 2 Departamento Académico de Ciencias Marinas y Costeras, Universidad Autónoma de Baja California Sur, La Paz, Baja California Sur, México \\ 3 Consejo Nacional de Ciencia y Tecnología, Ciudad de México, México \\ 4 Hopkins Marine Station and Center for Ocean Solutions, Stanford University, Pacific Grove, California, United States of America \\ 5 Institute for Marine and Antarctic Studies, University of Tasmania, Hobart, Tasmania, Australia \\ Corresponding Author: Georgina Ramírez-Ortiz \\ Email address: gramirez@pg.cibnor.mx
}

Multi-use marine protected areas (MUMPAs) are a commonly applied tool for marine conservation in developing countries, particularly where large no-take reserves are not socially or politically feasible. Although MUMPAs have produced benefits around the world, the persistence of moderate fishing pressure reduces the likelihood of achieving the primary objective of these areas, which is the conservation of ecosystems. In this study we used traditional and functional metrics to evaluate how fish assemblages changed through time in a MUMPA, including shifts in species responses and in ecological processes. We conducted visual censuses of fishes at Espíritu Santo Island, México (MUMPA; $N=320$; $24^{\circ} \mathrm{N}, 110^{\circ} \mathrm{W}$ ) from 2005 to 2017 to assess fish richness, size-distribution and density. Three functional indices were calculated using six traits (size, mobility, period of activity, aggregation, position in water column and diet): functional richness (volume occupied by species), dispersion (complementarity between species) and originality (inverse of functional redundancy). We compared fish diversity among three management zone types (sustainable fishing, traditional fishing and no-take zones), through a 13-year period, assessing which species increased or decreased in occurrence, density, and biomass, and how indices respond over time. Despite a general increase in biomass and stability in density and originality, we detected a reduction in fish biodiversity in the form of declines in species and functional richness, which could imply the risk of local extinction and decrease in certain ecosystem processes. In addition, changes in functional dispersion showed that some functions are losing representation through time. Although no single cause is apparent, such factors as competitive interactions, habitat loss and persistence of fishing pressure potentially explain these decreases. The rise in biomass was associated with a general increase in the average size, rather than increased biomass of commercial 
species, as the latter remained stable during the study period. Expansion of no-take areas, enforcement of fishing regulations, and surveillance in core zones, should be implemented to reverse the decline in particular species and to promote conservation of fish functional diversity in this MUMPA. 


\section{Reduced fish diversity despite increased fish biomass in a Gulf of California Marine}

\section{Protected Area}

3 Georgina Ramírez-Ortiz ${ }^{1}$, Héctor Reyes-Bonilla ${ }^{2}$, Eduardo F. Balart ${ }^{1}$, Damien Olivier ${ }^{2,3}$,

4 Leonardo Huato-Soberanis ${ }^{1}$, Fiorenza Micheli ${ }^{4}$, Graham J. Edgar ${ }^{5}$.

$5 \quad{ }^{1}$ Programa de Ecología Pesquera, Centro de Investigaciones Biológicas del Noroeste S.C., La

6 Paz, Baja California Sur, México.

72 Departamento Académico de Ciencias Marinas y Costeras, Universidad Autónoma de Baja

8 California Sur, La Paz, Baja California Sur, México.

$9{ }^{3}$ Consejo Nacional de Ciencia y Tecnología, Ciudad de México, México.

$10{ }^{4}$ Hopkins Marine Station and Center for Ocean Solutions, Stanford University, Pacific Grove,

11 California, United States of America.

$12{ }^{5}$ Institute for Marine and Antarctic Studies, University of Tasmania, Hobart, Tasmania,

13 Australia.

14

15 Corresponding author:

16 Georgina Ramírez-Ortiz.

17 Av. Instituto Politécnico Nacional 195, Playa Palo de Santa Rita Sur; La Paz, BCS, 23096, 18 México.

19 Email address: gramirez@pg.cibnor.mx 


\section{Abstract}

22 Multi-use marine protected areas (MUMPAs) are a commonly applied tool for marine 23 conservation in developing countries, particularly where large no-take reserves are not socially

24 or politically feasible. Although MUMPAs have produced benefits around the world, the

25 persistence of moderate fishing pressure reduces the likelihood of achieving the primary

26 objective of these areas, which is the conservation of ecosystems. In this study we used

27 traditional and functional metrics to evaluate how fish assemblages changed through time in a

28 MUMPA, including shifts in species responses and in ecological processes. We conducted visual

29 censuses of fishes at Espíritu Santo Island, México (MUMPA; N=320; $24^{\circ} \mathrm{N}, 110^{\circ} \mathrm{W}$ ) from

302005 to 2017 to assess fish richness, size-distribution and density. Three functional indices were

31 calculated using six traits (size, mobility, period of activity, aggregation, position in water

32 column and diet): functional richness (volume occupied by species), dispersion

33 (complementarity between species) and originality (inverse of functional redundancy). We compared fish diversity among three management zone types (sustainable fishing, traditional fishing and no-take zones), through a 13-year period, assessing which species increased or decreased in occurrence, density, and biomass, and how indices respond over time. Despite a general increase in biomass and stability in density and originality, we detected a reduction in fish biodiversity in the form of declines in species and functional richness, which could imply the risk of local extinction and decrease in certain ecosystem processes. In addition, changes in functional dispersion showed that some functions are losing representation through time. Although no single cause is apparent, such factors as competitive interactions, habitat loss and persistence of fishing pressure potentially explain these decreases. The rise in biomass was associated with a general increase in the average size, rather than increased biomass of commercial species, as the latter remained stable during the study period. Expansion of no-take areas, enforcement of fishing regulations, and surveillance in core zones, should be implemented to reverse the decline in particular species and to promote conservation of fish functional diversity in this MUMPA.

\section{Introduction}

Marine Protected Areas (MPA) are the most common and promising tool for mitigating anthropogenic disturbance (mainly fishing pressure) on marine ecosystems (Lester \& Halpern, 
51 2008; Lester et al., 2009; Bates et al., 2014). Nevertheless, different MPA schemes exist, from

52 the banning of all fishing activities (marine reserves), to multi-use marine protected areas

53 (MUMPA) that regulate fishing activities at different degrees, from restricted extraction (for

54 area, species captured, and gear employed) to complete prohibition areas (Agardy et al., 2003;

55 Sala \& Giakoumi, 2018). The benefits of fully-protected marine reserves on fish species richness, density and biomass have been demonstrated in many studies throughout the world, while MUMPAs show controversial results (Bates et al., 2014; Coleman et al., 2015; Campbell et al., 2018). For example, one analysis of 20 MUMPAs exhibited positive but non-significant responses for species richness, density and biomass, because even though industrial fisheries are banned from these areas, a moderate fishing pressure persist (restricted mainly on the fishing gear allowed) and may affect the populations of target species (Lester \& Halpern, 2008). In addition, some indirect effects of protection have been observed, especially in protected areas, where the maintenance or increase in the density of target species through reduced fishing pressure can cause a decline in non-target species due competitive and predatory interactions (Coleman et al., 2015, Ulate et al., 2018). Considering that direct and indirect effects of protection can structure communities in opposing or uncorrelated directions (Leendhardt et al., 2005), it is necessary to evaluate temporal changes to understand ecosystem dynamics within MUMPAs, especially in those areas which aim to protect irreplaceable biodiversity.

The Gulf of California (GC) is considered a hotspot of biological diversity (Roberts et al., 2002) and a key region for the fishing industry, providing $70 \%$ of the total catch in México (Cisneros-Mata, 2010; Díaz-Uribe et al., 2013). Although human population density is relatively low in the region, it is currently growing rapidly, and the GC is not exempt from global coastal and marine degradation trends (Lluch-Cota et al., 2007; Sagarin et al., 2008; Calderon-Aguilera et al., 2012). Since the mid-1980s the Mexican government has established several MPAs to conserve biodiversity and control extraction of natural resources (CONANP, 2007). However, all the MPAs in the GC are MUMPAs with small no-take areas surrounded by "buffer" zones where fishing effort is restricted (Rife et al., 2013). This is a planned strategy because the enactment of large no-fishing marine reserves is not socially and politically feasible in many developing countries (Halpern, 2003), and thus MUMPAs are the preferred alternative to safeguard the regional biodiversity and ensure a variety of ecosystem services (poverty reduction, coastal 
81 protection, recreation, tourism, and carbon sequestration) in addition to fish stock enhancement 82 (Spalding et al., 2013; Caveen et al, 2014;).

83 Few long-term studies have assessed the effects of MPAs in the GC. A two year

84 comparison of Parque Nacional Cabo Pulmo in 1999 and 2009 showed a rise in species richness

85 and biomass, especially of large carnivore fish species (Aburto-Oropeza et al., 2011), but another study in the same MPA comparing two different years (1987 and 2003), revealed a decrease in general species richness and fish density (Alvarez-Filip \& Reyes-Bonilla, 2006). Cabo Pulmo suffered from habitat deterioration between 1997 and 2003 due to impacts from hurricanes and El Niño Southern Oscillation events, which may have temporally damped the effect of protection. These observations underpin the limitations of short-term comparisons, especially those conducted between particular years, as they are not able to adequately capture the actual trends of natural and environmental variability, and the community response to them. On the other hand, a single continuous long-term study was carried out in the GC, at Parque Nacional Bahía de Loreto, another MUMPA (Rife et al., 2013). This 13-year long investigation revealed relatively stable total fish biomass but a decline in reported total fish landing, compared to open access sites. The authors concluded that, even if management strategies were not able to recover reef fish populations, at a minimum they should maintain the conditions of the ecosystem that existed when the park was established, which is not what they observed. However, a small notake zone (less than $1 \%$ of the total area) in this MUMPA presented significant biomass increases associated to a greater abundance of herbivorous and zooplanktivorous fishes in this zone. This result emphasizes the need of creation of larger no-take areas to improve reef fish populations and ensure sustainable fisheries far into the future. Such long-term studies need to be repeated throughout the GC and worldwide, to provide robust general assessments of the value of MUMPAs in conserving the living heritage, and in supplying natural resources to human local communities, and guidance for improving their management. (PNZMAES) was implemented in 2007 in the southwestern GC, a hotspot for reef fishes in the region (Olivier et al., 2018). This MUMPA encompasses exclusively the marine area around the entire Espíritu Santo archipelago and adjacent small isles, and is located less than $30 \mathrm{~km}$ from

110 the major regional population center: the city of La Paz, the capital of the state of Baja California

111 Sur, with over 300,000 inhabitants. The aim of this MPA is to conserve the ecosystems and 
112 ecological processes that occur in the area, while also allowing the use of the natural resources

113 under an integrated management scheme (CONANP-SEMARNAT, 2014). Thanks to the

114 collaboration of local fishermen, academics, civil organizations and federal authorities,

115 PNZMAES is considered successful, and in 2018 became the first national park of México

116 included in the Green List of Protected Areas by the International Union for the Conservation of

117 Nature (IUCN). This is a relevant global accolade as the list includes only 46 areas recognized

118 worldwide for effective management, governance, design and planning (IUCN, 2018).

119 The monitoring of reef ecosystems at PNZMAES began in 2005, two years before the

120 declaration of the protected area in 2007, and has continued without interruption to date.

121 Information derived from this systematic effort was used to design the management plan which

122 was published in 2014, in which the no-take (1.4\%) and "buffer" (98.6\%) zones were officially

123 designated (CONANP-SEMARNAT, 2014). The period covered by the monitoring program

124 provides an important opportunity to assess the effect of a MUMPA on the diversity of multiple 125 reef taxa.

126 In this paper we focus on reef fishes because this group plays important functional roles

127 in ecosystems, from herbivores which potentially control primary producer biomass (Mumby,

128 2009), to top predators that potentially control diverse mid trophic level taxa (Glynn \& Enochs,

129 2011; Holmlund \& Hammer, 1999). Moreover, fishes are economically relevant as they support

130 commercial fisheries and recreational activities (sport fishing and scuba diving; Leendhardt et

131 al., 2005). Given their role in shaping marine habitats and community structure, as well as their

132 importance for human livelihoods, it is critical to evaluate if temporal changes in fish species in

133 MUMPAs can alter ecological processes and ecosystem services (Miller, Roxburgh \& Shea,

134 2011; Mouillot et al., 2013).

135 Limited information is available about temporal changes of fish communities within

136 MUMPAs, and most of this has been based on traditional metrics (species richness, density and

137 biomass; Lester \& Halpern, 2008; Sala \& Giakoumi, 2018). This approach is useful and

138 descriptive, but omits critical information about a broader range of changes that may occur due

139 to protection, especially those related with ecosystem functioning (Coleman et al., 2015). In

140 order to effectively describe responses of fish assemblages to protection in terms of biological

141 diversity and their effects in ecological processes, recent studies have included functional

142 information of species that reveal their role in reef ecosystems (Bates et al., 2014; Coleman et al., 
143 2015). Assessing functional diversity in MPAs has allowed the detection of greater heterogeneity

144 in responses at species level (direct effects) and subtle changes at community level over time

145 (indirect effects; Coleman et al., 2015; Claudet et al., 2017).

146 In the current study we aimed to evaluate how fish assemblages changed through a 13-

147 year study period at PNZMAES, using traditional and functional metrics. We analyzed temporal

148 changes in the biomass of commercial species to detect direct effects of protection, and also

149 assessed if no-take and "buffer" zones followed similar trends of change or stability in traditional

150 and functional metrics through the study period. We tested three hypotheses: 1) fish species and

151 functional diversity in PNZMAES remain stable through time because the aim of the MUMPA is

152 to conserve ecosystems at the initial state (not to restore them); 2) biomass of commercial

153 species is maintained over time, and does not increase as a result of the moderate fishing

154 pressure that persists in the MUMPA; 3) fish assemblages in no-take zones present higher

155 diversity and more stability because of the total fishing ban in these areas (acting as reserves),

156 compared with "buffer" zones that possess lower diversity and slight changes through time due

157 moderate fishing pressure. This study also covers information gaps in the analysis of MPAs

158 because it incorporates novel metrics (functional diversity) and includes a continuous timeline

159 that allows a more comprehensive approach when assessing diversity changes over time.

160 Moreover, widespread increases in human population, tourism and fishing activities around

161 PNZMAES make this MUMPA an ideal test case for assessing the effects of partial protection in

162 the face of mounting anthropogenic pressures, as well as the potential value of replicating this

163 management strategy more widely, especially in developing countries.

\section{Materials \& Methods}

165 Study locations and data sampling

166 PNZMAES is located at the southwestern GC and encompasses an area of $486 \mathrm{~km}^{2}$

167 (2443'00” to $24^{\circ} 22^{\prime} 44^{\prime \prime} \mathrm{N}, 110^{\circ} 26^{\prime} 58^{\prime}$ ' to $\left.110^{\circ} 17^{\prime} 11^{\prime \prime} \mathrm{W}\right)$. This MPA was decreed in 2007 and,

168 even before the management plan was implemented in 2014 (CONANP-SEMARNAT, 2014),

169 park managers and fishermen established three levels of use in the area (Figure 1); no-take zones

170 where fishing is strictly prohibited ( 1.4\% of the MPA); and "buffer" zones divided into two

171 categories: traditional use zones where fishing activities with hook and line, and sport fishing are

172 allowed ( $4.4 \%$ of the MPA); and sustainable zones where, in addition to the activities in the 
173 traditional zones, aquaculture activities are also permitted (94.2\% of the MPA). Industrial

174 fisheries (including purse seining, long-lining and trawling) are prohibited in the entire MUMPA

175 (CONANP-SEMARNAT, 2014). Tourism activity exhibited an increase of 5\% in the number of

176 visitors from 2002 to 2007 (from 20,231 to 21,379 visitors; CONANP-SEMARNAT, 2014), with

177 numbers concentrated in the no-take area of "Los Islotes", which is dedicated to protect the

178 breeding colony of the sea lion Zalophus californiensis (Buchoul, 2016). More than two

179 surveillance trips were performed per day and a total of 84 penalties were registered from 2013

180 to 2017 (personal communication). Although fishing information is not available for PNZMAES,

181 fisheries catch databases from La Paz CONAPESCA office reported an increase of $133 \%$ of the

182 fish total catch from 2005 to 2016 (CONAPESCA, 2016).

183 From 2005 to 2017, eleven sites were monitored twice a year, in cold (January to June)

184 and warm (August to November) seasons (Figure 1). In each visited site, six to eight underwater

185 visual censuses of $100 \mathrm{~m}^{2}$ or $60 \mathrm{~m}^{2}$ were conducted. Different transect areas were considered in

186 the study period since the methodology changed following a park management decision in 2009.

187 Field surveys were approved by the dirección del Parque Nacional Zona Marina del Archipiélago

188 de Espíritu Santo of the Comisión Nacional de Áreas Naturales Protegidas

189 (PROMOBI/IGCBCS/003/2015, CONANP/PROMANP/MD/DRPBCPN/02/2016,

190 FOO.DRPBCPN.IGCBS.PNZMAES.-245-17).

To better consolidate the number of replicates, we aggregated data if visual census were

192 separated by less than $200 \mathrm{~m}$, and were performed the same day and depth range. From an

193 original 1546 sampling units we obtained a total of 320 transects (average $=333 \pm 73 \mathrm{~m}^{2}$, median

$194=300 \mathrm{~m}^{2}$; Electronic Supplementary Material ESM1), with 10\% of the surveys undertaken

195 before the inauguration of the MUMPA (2007), 65\% after the protection but before the

196 implementation of the management plan (2008-2014), and 25\% after the activation of specific

197 rules for fisheries in the MUMPA (ESM2, Table S1). For each transect, data on the number of

198 species (species richness) were collected, and with this information we constructed species

199 accumulation curves (randomization method) to analyze if we had a large enough sample to

200 adequately characterize the species pool in the study period. Using ANOVA we compared if

201 there were differences between transect areas $\left(180,200,240,300,360,400,540\right.$ and $\left.600 \mathrm{~m}^{2}\right)$,

202 given the aggregation of samples, as well as the changes in methodology and number of samples

203 per field campaign. Species accumulation curves and ANOVA were performed in R software 
204 with the "vegan" and "stats" R packages, respectively (Oksanen et al., 2010; R Development 205 Core Team, 2014).

206 In addition, abundance and individual fish size (to the nearest $5 \mathrm{~cm}$ ), were recorded for 207 each transect. Modal size was estimated for fishes in schools. Fish biomass $\left(\mathrm{g} / \mathrm{m}^{2}\right)$ was estimated 208 using the length-weight relation: Weight $=a^{*}$ Lengt $h^{\mathrm{b}}$, with coefficients $a$ and $b$ obtained from 209 FishBase (Froese \& Pauly, 2009).

210 Biological traits of fishes and diversity indices

211 To estimate the functional diversity of the fish assemblages, each fish species observed 212 was classified according to six categorical traits (nominal or ordinal) that reflect key aspects of 213 fish ecology (Mouillot et al., 2014): 1) maximum body size (ordinal: 0-7, 7-15, 15-30, 30-50, $21450-80,>80 \mathrm{~cm}$ ), 2) mobility (ordinal: low, medium within a reef, and high between reefs), 3)

215 period of activity (nominal: diurnal and nocturnal), 4) gregariousness (ordinal: solitary, pairing, 216 small groups and large groups), 5) vertical position in the water column (ordinal: benthic,

217 bentho-pelagic and pelagic), and 6) diet (nominal: herbivores-detritivores, invertivores targeting 218 sessile invertebrates, invertivores targeting mobile invertebrates, planktivores, apex predators

219 targeting fish and cephalopods and omnivores; ESM1). The same categories have been used in a 220 previous study in the GC (Olivier et al., 2018), and taken together they provide Functional 221 Entities (FEs).

222 The FEs were used to build a categorical traits matrix that was transformed into a 223 numerical matrix to calculate functional indices. Pairwise distances between species (according 224 to their FE) were computed using the Gower dissimilarity; this coefficient was selected because 225 it allows the use of different types of variables while giving them equal weight (Gower, 1971). A 226 principal coordinate analysis (PCoA) was performed using this functional dissimilarity matrix.

227 The number of axes used to calculate functional indices (first four axes) was determined $a$ 228 posteriori according to the method of Maire et al. (2015; Figure 2). These PCoA scores were 229 used to calculate three complementary functional diversity indices: functional richness, 230 functional dispersion, and functional originality (Villéger et al., 2008; Mouillot et al., 2013). The 231 definitions used here are the same as those of Mouillot et al. $(2013,2014)$. Functional richness 232 was defined as the volume covered by a set of species (for example those observed in a transect), 233 in proportion to the whole functional space encompassed by the outermost vertices of the 234 assemblage, which is determined on the basis of the complete species suite (Figure S1). This 
235 metric represents the range of functional niches found in a particular assemblage. Functional

236 dispersion was defined as the weighted mean distance between species present in a sampling

237 unit, and the weighted average position of the entire assemblage in the niche space (Figure S1).

238 This represents the functional complementarity between species. Functional originality was

239 defined as the weighted mean distance between each species and its nearest-neighbor in the niche

240 space (Figure S1), thus, the opposite of functional redundancy. The functional dispersion and

241 functional originality were weighted separately by the density and the biomass of each species.

242 We used the function "dbFD" and "multidimFD" from the "FD" $\mathrm{R}$ package to calculate the

243 different functional indices (Laliberté, Legendre \& Shipley, 2014). Data exploration of the eight

244 indices was carried out following the protocol described in Zuur, Ieno \& Elphick (2010). Density

245 and biomass were log-transformed (base 2) to achieve normality and homoscedasticity.

\section{Statistical analyses}

247 We ran linear mixed models (LMMs; Bolker, 2015) to compare the eight indices (species

248 richness, density, biomass, functional richness, functional dispersion weighted by density and

249 biomass, and functional originality weighted by density and biomass) against the three levels of

250 use of the MPA, i.e. no-take, traditional and sustainable zones. These analyses included as

251 random variables the potential effects of year, season and site; it is worth noting that by

252 considering site as random variable, we could account for spatial and temporal autocorrelation

253 associated with repeated monitoring of the same sites (Zuur et al., 2009). Season (cold or warm)

254 was also defined as a random variable as in the Gulf of California reef fish abundance and

255 biomass both decrease when temperature is low (Pérez-España et al., 1996; Aburto-Oropeza \&

256 Balart, 2001; Rodríguez-Romero et al., 2005). Year was taken as a random variable because we

257 wanted to compare the three levels of use independently of temporal changes, to determine if

258 there were differences in the eight indices associated with the variations in fishing restriction.

259 In addition, LMMs were also analyzed changes in fish diversity (eight indices

260 considered) through the 13-year period. Again we considered the potential effects of season and

261 site by including them as random factors, but in this case use level was not included in models

262 since it did not present significant differences for most of the indices calculated in the previous

263 analyses. Visual inspections of the residuals from each model did not reveal any severe violation

264 of parametric assumptions. 
To evaluate biomass changes in commercial species through the 13-year study period, we

266

267

268

269

270

271

272

273

274

275

276

277

278

279

280

281

282

283

284

285

286

287

288

289

290

291

292

293

294 ran a LMM considering site and season as random factors. The species involved in this analysis were selected from a list of commercial fishes present at PNZMAES (Niparajá, 2011), although out of the 42 species established as target species for the MUMPA, only 28 were observed in our reef surveys and considered for the analysis (ESM1).

The final analysis involved identification of which common species (present in at least $50 \%$ of the transects; 26 species) either increased ("winners") or decreased ("losers") in occurrence (presence of species per transect), density and biomass, through the 13-year study period. To do so, we applied generalized linear mixed models (GLMMs) with a binomial distribution for occurrence, and with a negative-binomial distribution for density and biomass, to account for overdispersion in the residuals (Zuur et al., 2009). Density and biomass values for each common species were rounded to an integer, a prerequisite to use the negative-binomial distribution, and site and season were considered as random variables. All statistical analyses were performed with the "Ime4" R package (Bates D et al., 2014).

\section{Results}

Species accumulation curves (ESM2, Figure S2a) indicate that 50 censuses provide an adequate sample to properly characterize the species pool in our area. Since we conducted a higher number of censuses in the field period, we have a standardized sample effort. Significant differences were found between transect areas $\left(\mathrm{F}_{7,312}=6.53, \mathrm{P}=<0.001\right)$, particularly among 180 and $600 \mathrm{~m}^{2}$ surveyed areas (ESM2, Figure S2b), which represent less than $4 \%$ of the total sample size. Our principal transect areas (300 and $400 \mathrm{~m}^{2}$, which represent $64 \%$ and $25 \%$ respectively), did not show significant differences $(\mathrm{P}=>0.05)$ between them.

The LMMs by level of use showed no significant differences $(\mathrm{P}>0.05)$ in most of the indices except density $(\mathrm{P}=0.02)$, which was higher where traditional fishing is allowed (Figure 3; ESM2, Table S2). Temporal LMMs indicated that species richness significantly decreased by $13 \%$ on average (confidence interval $(\mathrm{CI})=19 \%$ to $5 \%$ ) and biomass increased by $43 \%$ (CI: $2 \%$ to $99 \%$ ) through the 13-year study period (Figure 4; ESM2, Table S3). Nevertheless, the biomass of commercial species did not increase $(\mathrm{P}=0.30$; ESM2, Table $\mathrm{S} 4)$. Functional richness decreased $24 \%$ through the study period (CI: $34 \%$ to $14 \%$ ), while functional dispersion (complementarity among species), showed contrasting results: it increased $8 \%$ when weighted by 
295 density (CI: $6 \%$ to $11 \%$ ), and decreased $13 \%$ when calculated with biomass (CI: $19 \%$ to $8 \%$ ). No

296 change was observed for density and functional originality (Figure 4; ESM2, Table S3).

297 According to the LMMs (Figure 4), the temporal trends were similar in the three use

298 levels of the park when considering density and functional dispersion weighted by biomass

299 (decrease), as well as biomass and functional dispersion weighted by density (increase).

300 However, a biomass increase was more evident in the traditional use zones, and functional

301 dispersion (calculated using fish density) was higher in the sustainable use zones (Figure 4C;

302 Figure 4E). Concerning the species and functional richness, no significant changes were detected

303 where traditional fisheries are permitted, although significant decreases were observed in the

304 sustainable use and the no-take zones (Figure 4A; Figure 4D).

305 In relation to the study of changes in common reef fish species through time, we

306 identified 26 fishes present in at least 50\% of the 320 transects (Figure 5). GLMMs indicated that

307 seven of them decreased significantly in occurrence through time, and four of these "loser"

308 species were located on the outer margins of functional space (Figure 5D; Figure 5G). Only two

309 "winner" species increased significantly in occurrence (Figure 5A; ESM2, Table S5), while 17

310 remained stable through time. On the other hand, 12 common species decreased significantly in

311 density and they occupied a large part of the functional space (Figure 5E; Figure 5H), while six

312 "winner" species were identified (Figure 5B; ESM2, Table S6) and the remaining eight did not

313 present significant changes. Last, in the case of biomass, the number of fish species that

314 increased or decreased significantly was more balanced, with eight "winners" and six "losers"

315 (Figure 5C; ESM2, Table S7). The former were located near the aggregation of functional

316 centroids (expressed by the $95 \%$ ellipse), while the latter tended to occupy more outward

317 positions (Figure 5F; Figure 5I). The other 12 species did not change in biomass through 13

318 years of monitoring.

319 Discussion

320 Considering that, by law, the aim of PNZMAES is to conserve ecosystems in a state

321 similar to the original (before the establishment of the MUMPA; CONANP-SEMARNAT,

322 2014), MPA objectives would be met if no changes or increases in the values of species and

323 functional indices are observed. That is precisely what we found: a temporal increase in biomass

324 of the fish assemblage, and no significant changes in density and functional originality.

325 However, our hypothesis of stability in fish diversity through time cannot be fully accepted, 
326 since some indices (species richness, functional richness and functional dispersion weighted by

327 biomass) declined through the 13-year study period (Figure 4; ESM2, Table S3).

328 Temporal analyses indicated that species richness declined through time (independently

329 of the differences in sampling effort; ESM2, Figure S2). This result can be linked to the decrease

330 in functional richness, since some of the species that declined in the occurrence trend analysis

331 ("losers") were located at the outer margins of functional space. Their disappearance or decrease

332 in numbers caused a reduction in the functional space of the fish assemblage in these particular

333 years (Figure 5A; ESM2, Table S5). Fewer species and functional richness suggest local

334 extinction of species may ultimately occur (some with unique functional role), thereby risking

335 the maintenance of some ecosystem processes (Mouillot et al., 2013). A good example is the

336 endemic GC damselfish Chromis limbaughi, which declined in presence and abundance in the

337 park, and possesses an unusual role as a deep-water planktivore (Robertson \& Allen, 2015).

338 Functional dispersion, representing the ecological complementarity between species,

339 exhibited changes in the 13-year study period. Clearly the functional structure of the assemblage

340 is dynamic, reflecting variability in the distribution of density and biomass among species (Bates

341 et al., 2014). Changes in functional dispersion were evident when calculated on the basis of

342 density of individuals (Figure 5B), a pattern associated with an increase in abundance of certain

343 species ("winners") located far from the centroid (case 1 in Figure S1), and a decrease in

344 abundance of other species ("losers") distributed close to the centroid (case 2 in Figure S1). This

345 result demonstrates that in spite of the general stability in density of fishes at PNZMAES (Figure

346 4B; ESM2, Table S3) some functions are losing representation while others are gaining. This

347 could be associated with effects of protection on species (i.e. predatory and competitive

348 interactions) that have been observed elsewhere after an average of $13.1 \pm 2.0$ from

349 establishment of a MPA (Micheli \& Halpern, 2005; Babcock et al. 2010). Moreover, the increase

350 in abundance of species with different functions (widespread "winner" species) could favor the

351 resilience in the community by having more balanced, and thus similarly efficient

352 complementary functions (Mouillot et al., 2013).

353 By contrast, functional dispersion calculated from biomass showed a decline through

354 time, which could be explained by the distribution of biomass "winner" species around the center

355 of the functional space, while the "loser" species tended to occupy more extreme positions

356 (Figure 5F; Figure 5I). The fact that "winner" species were adjacent within functional space 
357 indicates that similar functions have been favored, mainly by the augmentation of size in their 358 individuals, since density trend analysis did not show a similar pattern (Figure 5E; Figure 5H).

359 Larger individuals of winner "species" have more impact in ecosystem functioning since their

360 ecological rates (i.e. consumption and production) are higher compared with smaller individuals

361 (Cyr et al., 1997), which could have caused changes in ecosystem processes in PNZMAES in the 362 study period.

363 The rise in biomass despite the stability in density of fishes (Figure 4B and 4C; ESM2,

364 Table S3), can also be explained as the result of an increment in fish size (Lester et al., 2009).

365 This was corroborated by analyzing the average size per year of the full fish assemblage, which

366 revealed an increase of 10\% between 2005 and 2017 (ESM2, Figure S3B). Interestingly, in other

367 MPAs this increase in average size is associated to direct effects of protection, in the form of

368 return or growth of commercial species due the reduction of fishing pressure (generally apex

369 predators with large size; Leendhardt et al., 2005). However, at PNZMAES the biomass of

370 commercial fishes did not exhibit significant changes through time (ESM2, Table S4), which

371 implies that non-target species are responsible for this increase. Similar patterns were also

372 observed in another GC MUMPA, Parque Nacional Bahía de Loreto, where biomass of

373 herbivorous and planktivorous non-commercial species increased after 13-years of protection

374 (1998-2010) in a small no-take area (1.27 km²; Rife et al., 2013). Overall, this result corroborates

375 our stability hypothesis for the commercially important species group due the persistence of

376 moderate fishing pressure in this MUMPA.

377 Predation and cascading trophic effects by commercial species do not seem to be the

378 main drivers of change in fish assemblages in PNZMAES, as has been observed in other MPAs

379 shortly after protection ( $5.13 \pm 1.9$ years; Babcock et al. 2010$)$. Other factors, such as

380 competitive interactions, habitat quality and fishing activities, could explain the simultaneous

381 increase and decline of different species (Leendhardt et al., 2005). Possible examples of

382 competition are the increase observed in the parrotfish species Scarus compressus and the

383 decrease of Scarus rubroviolaceus (ESM1) in the density and biomass trend analyses (Table S6

384 and S7, ESM2). Given that these species share all the ecological traits considered in this study

385 (and thus could be considered redundant), the possible substitution among species should not

386 represent a threat for their essential functions and ecosystem services in eastern Pacific reef

387 environments. Such functions include bioerosion and later deposition of carbonate sediment, 
388 which helps in the construction of the reef framework, and the magnitude of herbivory, which

389

390

391

392

393

394

395

396

397

398

400

401

402

403

404

405

406

407

408

409

410

411

412

413

414

415

416

417

418 influences nutrient cycles and controls algae proliferation (Bellwood, Hoey \& Hughes, 2011).

Related to habitat quality, the particular case of a decrease in density and biomass of the coral hawkfish Cirrithichthys oxycephalus (Figure 5B; Figure 5C), is an example of a species with unique function (ESM1) that is threatened under the conditions of PNZMAES. The decrease of this species has been linked to coral cover loss in Parque Nacional Cabo Pulmo, caused by repeated hurricane impacts and the 1997-1998 El Niño event (Iglesias-Prieto et al., 2003; Alvarez-Filip \& Reyes-Bonilla, 2006). Considering that in PNZMAES coral cover significantly declined $(b=-0.44$; ESM2, Figure $\mathrm{S} 3 \mathrm{~A}$ ), habitat loss represents an important issue and focus for future conservation efforts in this MUMPA, to prevent local extinction of coralassociated species.

In the case of possible fishing effects, the decrease in occurrence and biomass of the commercially important leopard grouper Mycteroperca rosacea (Figure 5A, Figure 5C) is indicative of removal of large-sized individuals. Although IUCN has classified this species as "Least Concern" (Erisman \& Craig, 2018), a decline in abundance has been reported from over a decade ago (Sala et al., 2004) because it is one of the most intensely fished groupers in the GC (Sala et al., 2003; TinHan et al., 2014). Given the key ecological role of the leopard grouper in reef ecosystems as a high level carnivore (in adult stages over $36.5 \mathrm{~cm}$ TL; Moreno-Sánchez et al., 2019), and its economic importance by representing a high proportion of the annual fishing revenue (78\% in combination with snappers; Tinhan et al., 2014), enhanced protection strategies are needed for stabilization and recovery of population numbers within the region.

Protection efforts for commercial species are, however, difficult because most of these species are large and have high movement capacity (Munguia-Vega et al., 2018), travelling distances (e.g. $15 \mathrm{~km}$; TinHan et al., 2014) that can exceed the maximum span of local no-take zones $(2.5 \mathrm{~km})$. A balance between loss of fishes in "buffer" zones due fishing activities and emigration from no-take zones, could explain the observed functional homogeneity in space and time of PNZMAES fish assemblages, which presented similar values and temporal trends for most of the indices (Figure 3; Figure 4). These results are not consistent with the hypothesis that ecological and functional performance is greater in no-take zones, because the entire MUMPA apparently behaves as a unit. In this particular case, an expansion of the no-take zones should help protect highly mobile commercial species (Munguia-Vega et al. 2018), and could clarify the 
419 benefits of a total fishing ban. Improved conservation outcomes have been reported in Parque 420 Nacional Cabo Pulmo ( $25 \mathrm{~km}^{2}$ of core area), which exhibited a $463 \%$ increase of total fish 421 biomass and a 30\% increase in biomass of predatory fishes between 1999 and 2009 (Aburto422 Oropeza et al., 2011).

423 In addition to the expansion of the no-take areas, other local strategies such as 424 surveillance of important zones and restrictions on use of fishing gears by local fishermen, 425 should be enhanced to counteract the observed decline in abundance and occurrence of particular 426 species that have deteriorated functional richness in the MUMPA (Figure 4A; Figure 4D). To 427 conduct these programs, the collaboration of the local residents is essential if the conservation 428 aim of the MPA is to be achieved. New developments, including the recent addition of 429 PNZMAES to the IUCN Green List of Protected Areas (2018), provides an opportunity to obtain 430 human and logistic resources to improve local management in co-responsibility with local 431 stakeholders, and reverse the observed decline in fish diversity over the last decade. 432 In conclusion, this study demonstrates that the conservation aim of PNZMAES has not 433 been fully accomplished because, despite a long-term increase in biomass and stability in density 434 and functional originality, some indices significantly declined between 2005 and 2017. Declines 435 in species and functional richness could indicate possible local extinctions and the loss of certain 436 ecosystem processes, such as those associated with competitive interactions, habitat loss and 437 fishing activities. However, changes in functional dispersion indicate that the functional structure 438 of the fish assemblage is dynamic: while some species are losing representation through time, 439 others are gaining. Furthermore, biomass increase was associated with a general increase in 440 individual fish size through time, rather than to an increase in presence or growth of commercial 441 species. Populations of commercial fishes remained stable in the face of moderate fishing 442 pressure persisting in the area. Finally, no-take zones presented similar temporal trends and 443 values of diversity in comparison with "buffer" zones, which indicates that the entire MUMPA is 444 behaving as a unit, possibly through dispersal and connectivity between zones. Local 445 management strategies, which should include expansion of the no-take areas, habitat 446 preservation, fishing regulations and support of local community, should be taken to overturn the 447 decline in particular species and to promote the conservation of fish functional diversity in this 448 and other MUMPAs in the GC. 


\section{Acknowledgments}

450 We thank all the people and institutions (CICIMAR, UABCS and Niparajá) who participated in

451 field surveys of the monitoring program of Sociedad de Historia Natural Niparajá, A.C. (2005-

452 2014, 2017) and Comisión Nacional de Áreas Naturales Protegidas (2015, 2016). We thank

453 CIBNOR for the facilities and support to develop this research.

\section{References}

455 Aburto-Oropeza O, Erisman B, Galland GR, Mascareñas-Osorio I, Sala E, Ezcurra, E. 2011.

456 Large recovery of fish biomass in a no-take marine reserve. PLoS One 6(8): DOI:

457

458 10.1371/journal.pone.0023601

Aburto-Oropeza O \& Balart EF. 2001. Community structure of reef fish in several habitats of a rocky reef in the Gulf of California. Marine Ecology 22(4): 283-305 DOI: 10.1046/j.14390485.2001.01747.x

Agardy T, Bridgewater P, Crosby MP, Day J, Dayton PK, Kenchington R, Laffoley D, McConney P, Murray PA, Parks JE, Peau L. 2003. Dangerous targets? Unresolved issues and ideological clashes around marine protected areas. Aquatic Conservation: Marine and Freshwater Ecosystems 13(4): 353-367 DOI: 10.1002/aqc.583

Alvarez-Filip L, Reyes-Bonilla H. 2006. Comparison of community structure and functional diversity of fishes at Cabo Pulmo coral reef, western Mexico between 1987 and 2003. Proceedings of 10th International Coral Reef Symposium 2: 16-225

Babcock RC, Shears NT, Alcala AC, Barrett NS, Edgar GJ, Lafferty KD, McClanahan TR, Russ, GR. 2010. Decadal trends in marine reserves reveal differential rates of change in direct and indirect effects. Proceedings of the National Academy of Sciences 107(43): 18256-18261 DOI: 10.1073/pnas.0908012107

Bates AE, Barrett NS, Stuart-Smith RD, Holbrook NJ, Thompson PA, Edgar GJ. 2014. Resilience and signatures of tropicalization in protected reef fish communities. Nature

Bates D, Maechler M, Bolker B, Walker S. 2014. lme4: Linear mixed-effects models using Eigen and S4. R Package Version 1.1-7 Available at http://cran. r-project. org> (accessed 02 November 2018).

Bellwood DR, Hoey AS, Hughes TP. 2011. Human activity selectively impacts the ecosystem roles of parrotfishes on coral reefs. Proceedings of the Royal Society B: Biological Sciences 
Bolker BM. 2015. Linear and generalized linear mixed models. In: Fox GA, NegreteYankelevich S, Sosa VJ, eds., Ecological statistics. Contemporary theory and application. New York: Oxford University Press, 309-333

Buchoul AP. 2016. Capacidad de carga turística por buceo y senorkel en Los Islotes, Parque Nacional Archipiélago Espíritu Santo. Master in Science Thesis, CIBNOR. Available at http://dspace.cibnor.mx:8080/handle/123456789/500 (accessed 10 December 2019)

Calderon-Aguilera LE, Rivera-Monroy VH, Porter-Bolland L, Martínez-Yrízar A, Ladah LB, Martínez-Ramos M, Alcocer J, Santiago-Pérez AL, Hernández-Arana HA, Reyes-Gómez VM, Pérez-Salicrup DR, Díaz-Nuñez V, Sosa-Ramírez J, Herrera-Silveira J, Búrquez A. 2012. An assessment of natural and human disturbance effects on Mexican ecosystems: Current trends and research gaps. Biodiversity and Conservation 21(3): 589-617 DOI: 10.1007/s10531-011-0218-6

Campbell SJ, Edgar GJ, Stuart-Smith RD, Soler G, Bates AE. 2018. Fishing-gear restrictions and biomass gains for coral reef fishes in marine protected areas. Conservation Biology 32(2): 401-410 DOI: 10.1111/cobi.12996

Caveen A, Polunin N, Gray T, Stead SM. 2014. The controversy over marine protected areas: science meets policy. Switzerland: Springer.

Cisneros-Mata MA. 2010. The importance of fisheries in the Gulf of California and ecosystembased sustainable co-management for conservation. In: Brusca RC, ed., The Gulf of California: Biodiversity and Conservation. Tucson: University of Arizona Press and the Arizona-Sonora Desert Museum, 119-134.

Claudet J. 2017. Six conditions under which MPAs might not appear effective (when they are). ICES Journal of Marine Science, 75(3): 1172-1174 DOI: 10.1093/icesjms/fsx074

Coleman MA, Bates AE, Stuart-Smith RD, Malcolm HA, Harasti D, Jordan A, Knott NA, Edgar GJ, Kelaher BP. 2015. Functional traits reveal early responses in marine reserves following protection from fishing. Diversity and Distributions 21(8): 876-887

DOI:10.1111/ddi.12309

CONANP. 2007. Programa Nacional de Áreas Naturales Protegidas. México, DF: SEMARNAT. Available at https://www.conanp.gob.mx/documentos/PNANP20142018.pdf (accessed 18 January 2018). 
511 CONANP-SEMARNAT. 2014. Programa de manejo del Parque Nacional exclusivamente la

512 zona marina del Archipiélago de Espíritu Santo. México DF: CONANP-SEMARNAT.

513 Available at https://bpo.sep.gob.mx/\#/recurso/1795/document/1 (accessed 18 January

514 2018).

515 CONAPESCA. 2016. Anuario estadístico de acuacultura y pesca. Available at

516 https://www.gob.mx/conapesca/documentos/anuario-estadistico-de-acuacultura-y-pesca

517 (accessed 22 January 2020).

518 Cyr H, Downing JA, Peters RH. 1997. Density-body size relationships in local aquatic

519 communities. Oikos, 79(2): 333-346 DOI: $10.2307 / 3546017$

520 Díaz-Uribe JG, Valdez-Ornelas VM, Danemann GD, Torreblanca-Ramírez E, Castillo-López A,

521 Cisneros-Mata MÁ. 2013. Regionalización de la pesca ribereña en el noroeste de México

522 como base práctica para su manejo. Ciencia Pesquera 21(1): 41-54 DOI:

$523 \quad 10.14350 /$ rig. 56674

524 Erisman B, Craig MT. 2018. Mycteroperca rosacea. The IUCN Red List of Threatened Species

525 2018: e.T14053A100466656. Available at https://dx.doi.org/10.2305/IUCN.UK.2018-

526 2.RLTS.T14053A100466656.en (accessed 20 January 2019).

527 Froese R, Pauly D. 2009. FishBase. Available at https://www.fishbase.se/search.php (accessed

52823 November 2018).

529 Glynn PW, Enochs IC. 2011. Invertebrates and their roles in coral reef ecosystems. In: Dubinsky

530 Z, Stambler N, eds., Coral reefs: an ecosystem in transition. London: Springer, 273-325

531 DOI: $10.1007 / 978-94-007-0114-4$

532 Gower JC. 1971. A general coefficient of similarity and some of its properties. Biometrics 27:

533 857-871. DOI: $10.2307 / 2528823$

534 Halpern BS. 2003. The impact of marine reserves: do reserves work and does reserve size

535 matter? Ecological Applications 13: 117-137 DOI: 10.1890/1051-

536 0761(2003)013[0117:TIOMRD]2.0.CO;2

537 Hernández-Camacho CJ, Aurioles-Gamboa D, Gerber LR. 2008. Age-specific birth rates of

538 California sea lions (Zalophus californianus) in the Gulf of California, Mexico. Marine

539 Mammal Science 24(3): 664-676 DOI: 10.1111/j.1748-7692.2008.00199.x

540 Holmlund CM, Hammer M. 1999). Ecosystem services generated by fish populations.

541 Ecological Economics, 29(2): 253-268 ISSN: 0921-8009 
542 Iglesias-Prieto R, Reyes-Bonilla H, Riosmena-Rodríguez R. 2003. Effects of 1997-1998 ENSO

543

544

545

546

547

548

549

550

551

552

553

554

555

556

557

558

559

560

561

562

563

564

565

566

567

568

569

570

571

572

on coral reef communities in the Gulf of California, Mexico. Geofisica Internacional, 42: 467-471 ISSN: 0016-7169

IUCN. 2018. Available at https://www.iucn.org/theme/protected-areas/our-work/iucn-green-listprotected-and-conserved-areas/iucn-green-list-areas (accessed 21 Mayo 2019)

Laliberté E, Legendre P, Shipley B. 2014. FD: measuring functional diversity from multiple traits, and other tools for functional ecology. R package ver. 1.0-12.

Leenhardt, P, Low N, Pascal N, Micheli F, Claudet J. 2015. The role of marine protected areas in providing ecosystem services. In: Belgrano A, Woodward G, Jacob U, eds., Aquatic functional biodiversity: an ecological and evolutionary perspective. London: Academic Press, 211-239 DOI: 10.1016/B978-0-12-417015-5.00009-8

Lester SE, Halpern BS. 2008. Biological responses in marine no-take reserves versus partially protected areas. Marine Ecology Progress Series 367: 49-56 DOI: 10.3354/meps07599

Lester SE, Halpern BS, Grorud-Colvert K, Lubchenco J, Ruttenberg BI, Gaines SD, Airamé S, Warner, R. R. 2009. Biological effects within no-take marine reserves: a global synthesis. Marine Ecology Progress Series 384: 33-46 DOI: 10.3354/meps08029

Lluch-Cota SE, Aragón-Noriega EA, Arreguín-Sánchez F, Aurioles-Gamboa D, Jesús BautistaRomero J, Brusca RC, Cervantes-Duarte R, Corté-s-Altamirano R, Del-Monte-Luna P, Esquivel-Herrera A, Fernández G, Hendrickx ME, Hernández-Vázquez S, HerreraCervantes H, Kahru M, Lavín M, Lluch-Belda D, Lluch-Cota DB, López-Martínez J, Marinone SG, Nevárez-MArtínez MO, Parés-Sierra A, Ponce-Díaz G, Ramírez-Rodríguez M, Salinas-Zavala CA, Schwartzlose RA, Sierra-Beltrán AP. 2007. The Gulf of California: Review of ecosystem status and sustainability challenges. Progress in Oceanography 73(1): 1-26 DOI: 10.1016/j.pocean.2007.01.013

Maire E, Grenouillet G, Brosse S, Villéger S. 2015. How many dimensions are needed to accurately assess functional diversity? A pragmatic approach for assessing the quality of functional spaces. Global Ecology and Biogeography 24(6): 728-740 DOI: 10.1111/geb.12299

Micheli F, Halpern BS. 2005. Low functional redundancy in coastal marine assemblages. Ecology Letters 8(4), 391-400 DOI: 10.1111/j.1461-0248.2005.00731.x

Miller AD, Roxburgh SH, Shea K. 2011. How frequency and intensity shape diversity- 
573

574

575

576

577

578

579

580

581

582

583

584

585

586

587

588

589

590

591

592

593

594

595

596

597

598

599

600

601

602

603

disturbance relationships. Proceedings of the National Academy of Sciences 108(14): 56435648 DOI: $10.1073 /$ pnas.1018594108

Moreno-Sanchez XG, Perez-Rojo P, Irigoyen-Arredondo MS, Marin-Enriquez E, AbitiaCárdenas LA, Escobar-Sanchez O. 2019. Feeding habits of the leopard grouper, Mycteroperca rosacea (Actinopterygii: Perciformes: Epinephelidae), in the central Gulf of California, BCS, Mexico. Acta Ichthyologica et Piscatoria 49(1): 9-22 DOI: 10.3750/AIEP/02321

Mouillot D, Graham NAJ, Villéger S, Mason NWH, Bellwood DR. 2013. A functional approach reveals community responses to disturbances. Trends in Ecology and Evolution 28(3): 167177 DOI: 10.1016/j.tree.2012.10.004

Mouillot D, Villéger S, Parravicini V, Kulbicki M, Arias-González JE, Bender M, Chabanet P, Floeter SR, Friedlander A, Vigliola L, Bellwood DR. 2014. Functional over-redundancy and high functional vulnerability in global fish faunas on tropical reefs. Proceedings of the National Academy of Sciences of the United States of America 111(38): 13757-13762 DOI: 10.1073/pnas. 1317625111

Mumby PJ. 2009. Herbivory versus corallivory: are parrotfish good or bad for Caribbean coral reefs? Coral Reefs 28(3), 683-690 DOI: 10.1007/s00338-009-0501-0

Munguia-Vega A, Green AL, Suarez-Castillo AN, Espinosa-Romero MJ, Aburto-Oropeza O, Cisneros-Montemayor AM, Cruz-Piñón G, Danemann G, Giron-Nava A, Gonzalez-Cuellar O, Lasch C, Mancha-Cisneros MM, Marinone SG, Moreno-Báez M, Morzaria-Luna HN, Reyes-Bonillea H, Torre J, Turk-Boyer P, Walther M, Hudson-Weaver A. 2018. Ecological guidelines for designing networks of marine reserves in the unique biophysical environment of the Gulf of California. Reviews in Fish Biology and Fisheries 28(4): 749-776 DOI: $10.1007 / \mathrm{s} 11160-018-9529-\mathrm{y}$

Niparajá AC. 2011. Guía de identificación de pesquerías comerciales ribereñas. Baja California Sur, México. La Paz, BCS: Niparajá A.C. Available at http://niparaja.org/file/2015/06/GUIA-DE-IDENTIFICACION-DE-PESQUERIASCOMERCIALES-RIBERENAS.pdf

Oksanen J, Blanchet FG, Kindt R, Legendre P, O’hara RB, Simpson GL, Solymos P, Stevens MHH, Wagner H. 2010. Vegan: community ecology package. R package version 1.17-4. Available at http://cran. r-project. org> (accessed 12 November 2019). 
604 Olivier D, Loiseau N, Petatán-Ramírez D, Trujillo-Millán O, Suárez-Castillo AN, Torre J, 605 Munguia-Vega A, Reyes-Bonilla H. 2018. Functional-biogeography of the reef fishes of the 606 islands of the Gulf of California : Integrating functional divergence into marine 607 conservation. Global Ecology and Conservation 16: e00506 DOI:

$608 \quad$ 10.1016/j.gecco.2018.e00506

609 Pérez-España H, Galvan-Magaña F, Abitia-Cárdenas LA. 1996. Variaciones temporales y 610 espaciales en la estructura de la comunidad de peces de arrecifes rocosos del suroeste del 611 Golfo de California, México. Ciencias Marinas 22(3): 273-294 DOI:

$612 \quad / 10.7773 / \mathrm{cm} . \mathrm{v} 22 \mathrm{i} 3.864$

613 R Development Core Team. 2014. R: A language and environment for statistical computing. 614 Vienna, Austria: R Foundation for Statistical Computing.

615 Rife AN, Aburto-Oropeza O, Hastings PA, Erisman B, Ballantyne F, Wielgus J, Sala E, Gerber, 616 L. 2013. Long-term effectiveness of a multi-use marine protected area on reef fish assemblages and fisheries landings. Journal of Environmental Management 117: 276-283 DOI: 10.1016/j.jenvman.2012.12.029

Roberts CM, McClean CJ, Veron JEN, Hawkins JP, Allen GR, McAllister DE, Mittermeier CG, Schueler FW, Spalding M, Wells F, Vynne C, Werner TB. 2002. Marine biodiversity hotspots and conservation priorities for tropical reefs. Science, 295(5558): 1280-1284 DOI: 10.1126/science. 1067728

Robertson DR, Allen GR. 2015. Shorefishes of the Tropical Eastern Pacific: online information system. Version 2.0. Smithsonian Tropical Research Institute. Available at https://biogeodb.stri.si.edu/sftep/en/pages (accessed 18 December 2019).

Rodríguez-Romero J, Muhlia-Melo AF, Galván-Magaña F, Gutiérrez-Sánchez FJ, Gracia-Lopez V. 2005. Fish assemblages around Espíritu Santo island and Espíritu Santo seamount in the lower Gulf of California, Mexico. Bulletin of Marine Science, 77(1): 33-50.

Sagarin RD, Gilly WF, Baxter CH, Burnett N, Christensen J. 2008. Remembering the Gulf: Changes to the marine communities of the Sea of Cortez since the Steinbeck and Ricketts expedition of 1940. Frontiers in Ecology and the Environment 6(7): 372-379 DOI: $10.1890 / 070067$

Sala E, Aburto-Oropeza O, Paredes G, Thompson G. 2003. Spawning aggregations and reproductive behavior of reef fishes in the Gulf of California. Bulletin of Marine Science 
635

636

637

638

639

640

641

642

643

644

645

646

647

648

649

650

651

652

653

654

655

656

657

658

659

72(1): 103-121

Sala E, Aburto-Oropeza O, Reza M, Paredes G, López-Lemus LG. 2004. Fishing down coastal food webs in the Gulf of California. Fisheries 29(3): 19-25 DOI: 10.1577/15488446(2004)29[19:FDCFWI]2.0.CO;2

Sala E, Giakoumi S. 2018. No-take marine reserves are the most effective protected areas in the ocean. ICES Journal of Marine Science 75(3): 1166-1168 DOI: 10.1093/icesjms/fsx059

Spalding MD, Meliane I, Milam A, Fitzgerald C, Hale LZ. 2013. Protecting marine spaces: global targets and changing approaches. Ocean Yearbook Online 27(1): 213-248 DOI: $10.1163 / 22116001-90000160$

TinHan T, Erisman B, Aburto-Oropeza O, Weaver A, Vázquez-Arce D, Lowe CG. 2014. Residency and seasonal movements in Lutjanus argentiventris and Mycteroperca rosacea at Los Islotes Reserve, Gulf of California. Marine Ecology Progress Series 501: 191-206 DOI: $10.3354 /$ meps 10711

Ulate K, Alcoverro T, Arthur R, Aburto-Oropeza O, Sánchez C, Huato-Soberanis L. 2018. Conventional MPAs are not as effective as community co-managed areas in conserving topdown control in the Gulf of California. Biological Conservation 228: 100-109 DOI: 10.1016/j.biocon.2018.09.033

Villéger S, Mason NWH, Mouillot D. 2008. New Multidimensional Functional Diversity Indices for a Multifaceted Framework in Functional Ecology. Ecology 89(8): 2290-2301 DOI: $10.1890 / 07-1206.1$

Zuur AF, Ieno EN, Elphick CS. 2010. A protocol for data exploration to avoid common statistical problems. Methods in ecology and evolution 1(1): 3-14 DOI: 10.1111/j.2041210X.2009.00001.X

Zuur AF, Ieno EN, Walker NJ, Saveliev AA, Smith GM. 2009. Mixed effects models and extensions in ecology with R. New York: Spring Science and Business Media. 


\section{Figure 1}

Figure 1. Location of the surveyed sites in the Parque Nacional exclusivamente la zona marina del Archipiélago de Espíritu Santo (PNZMAES).

The points represent each site surveyed and the levels of use are color-coded: No-take zones in blue (Islotes, Punta Lobos, Bonanza and San Gabriel), Traditional use zones in orange (Bajito, Tijeretas and Swanny), and Sustainable use zones in green (Cardonal, Ballena, Gallo and Pailebote). The rectangle-polygons represent the area with traditional use (yellow-filled) and the no-take zones (blue-filled). 


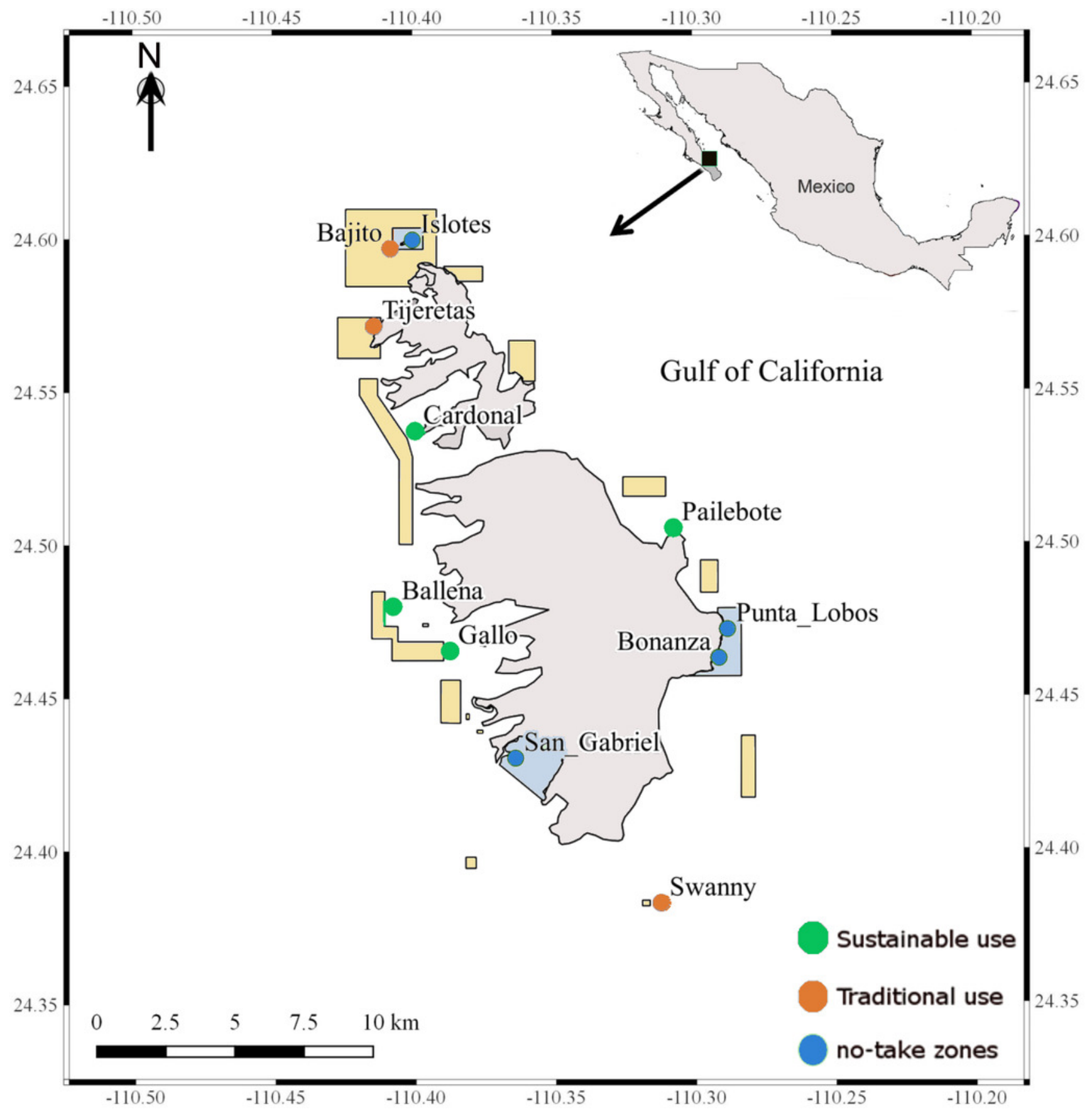




\section{Figure 2}

Figure 2. Functional space (first four PCoA axes) of the fish species in PNZMAES.

A) For PC1 and PC2, each point represents a species and the color corresponds to their functional traits: low mobility and gregariousness (blue), high mobility and gregariousness (red), bentho-pelagic or pelagic and diurnal species (yellow), benthic and nocturnal species (green). B) The convex hulls for each trophic group are represented along PC3 and PC4: herbivores-detritivores (HD), planktivores (Pk), invertivores targeting sessile invertebrates (IS), invertivores targeting mobile invertebrates (IM), apex predators targeting fish and cephalopods (FC), and omnivores (O).
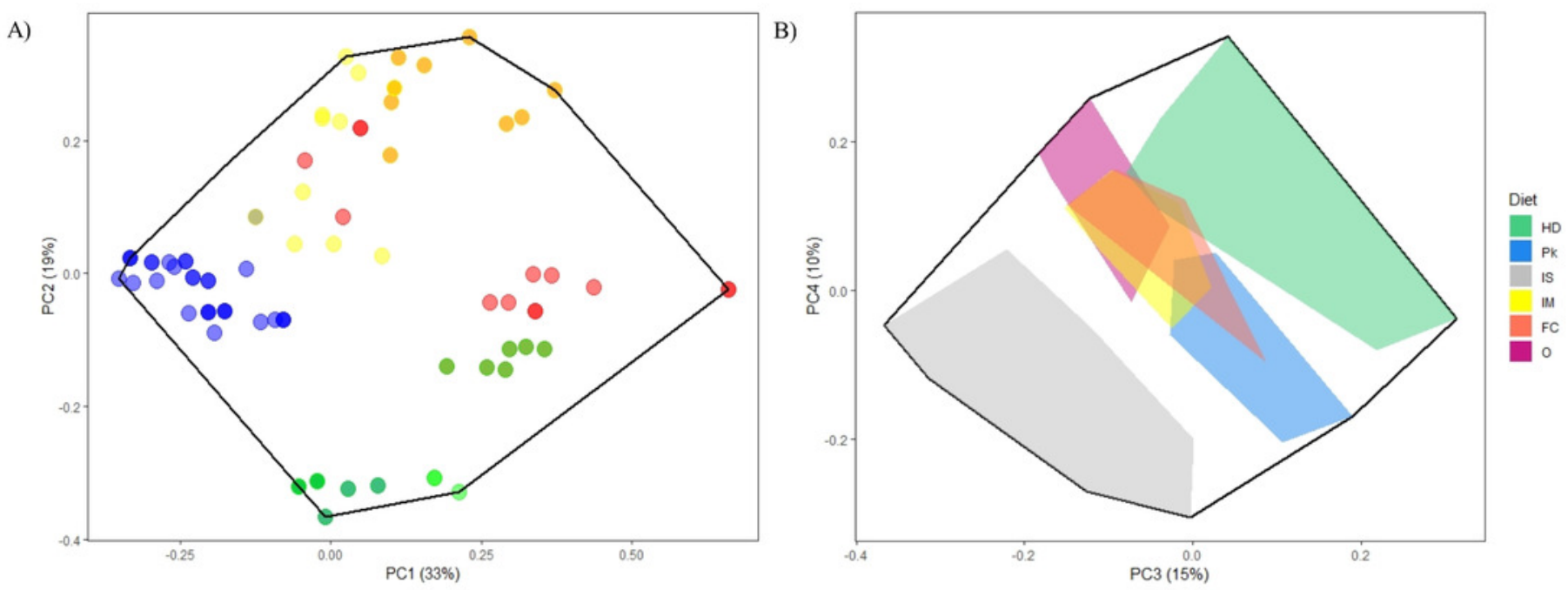
Figure 3

Figure 3. Comparison of fish diversity between levels of use in PNZMAES by ANOVA ( $\alpha=$ 0.05).

The density and biomass have been log-transformed (base 2). The red asterisk indicates a significant difference among the levels of use. The boxplots depict the mean, 2nd and 3rd quartiles, the confidence interval (95\%) and the outlier dots.

A)

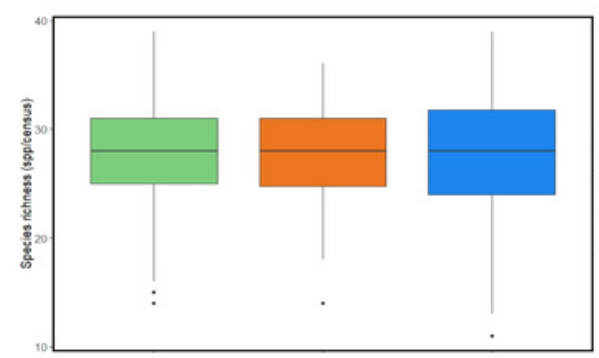

D)

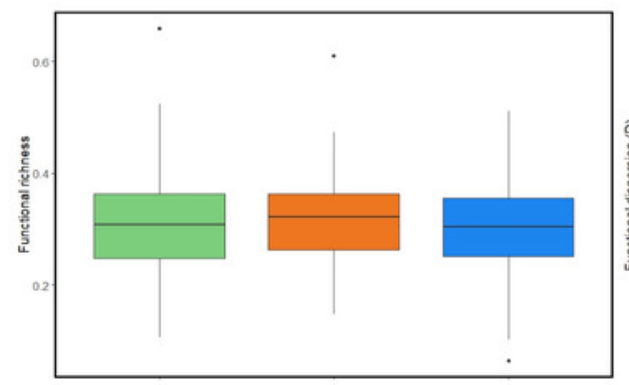

G)

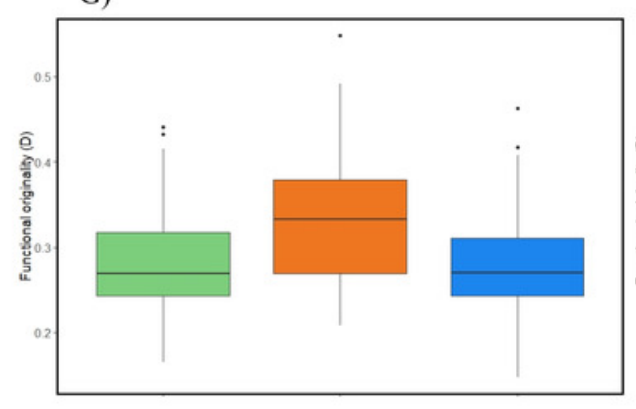

B)

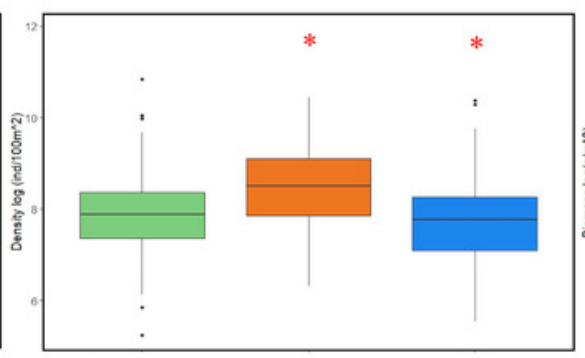

E)

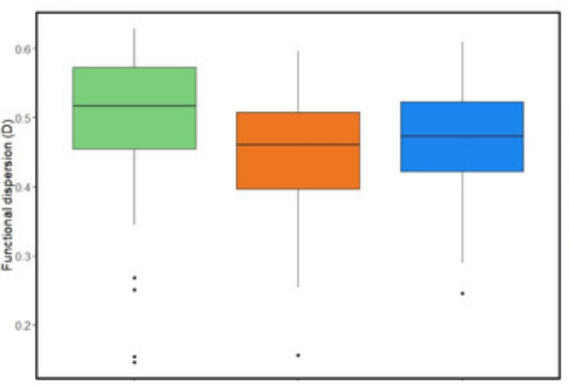

$\mathrm{H})$

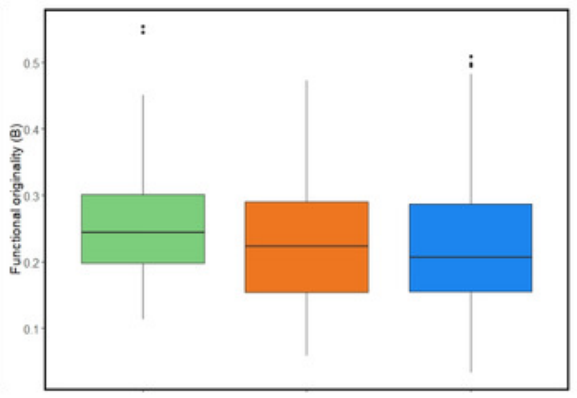

C)

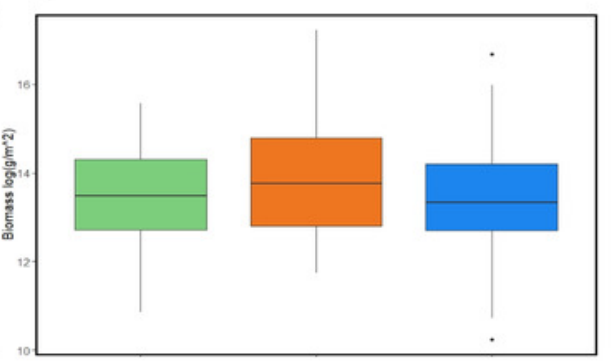

F)

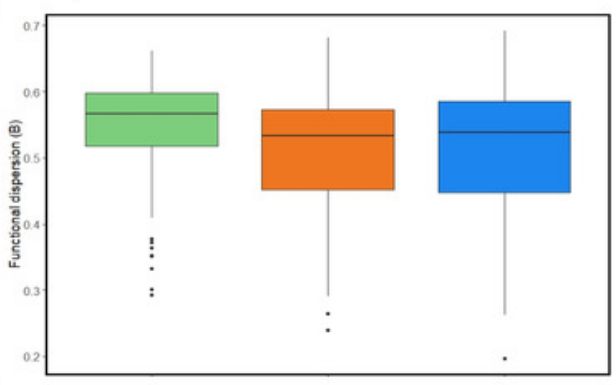

Sustainable use

Traditional use

No-take zones 


\section{Figure 4}

Figure 4. Temporal trends of the fish diversity along a 13-year study period in PNZMAES.

Regression lines for linear models are shown for each ecological and functional index. A jitter position has been added to handle overplotting of the data. The colors of regression lines are according to the level of use in the park, i.e., green: sustainable, orange: traditional, and blue: no-take zones. The coefficient estimates (mean $\pm 95 \%$ confidence interval) of the LMMs considering the 11 sites are shown for the eight indices calculated. Coefficients have been standardized for visualization. Green and red circles show significant positive and negative changes, respectively. Grey symbols indicate no significant changes. $D$ and $B$ indicate if that index was weighted by density (D) or biomass (B). 
A)

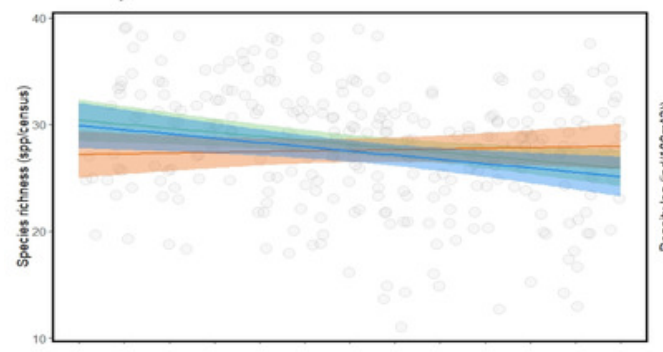

D)
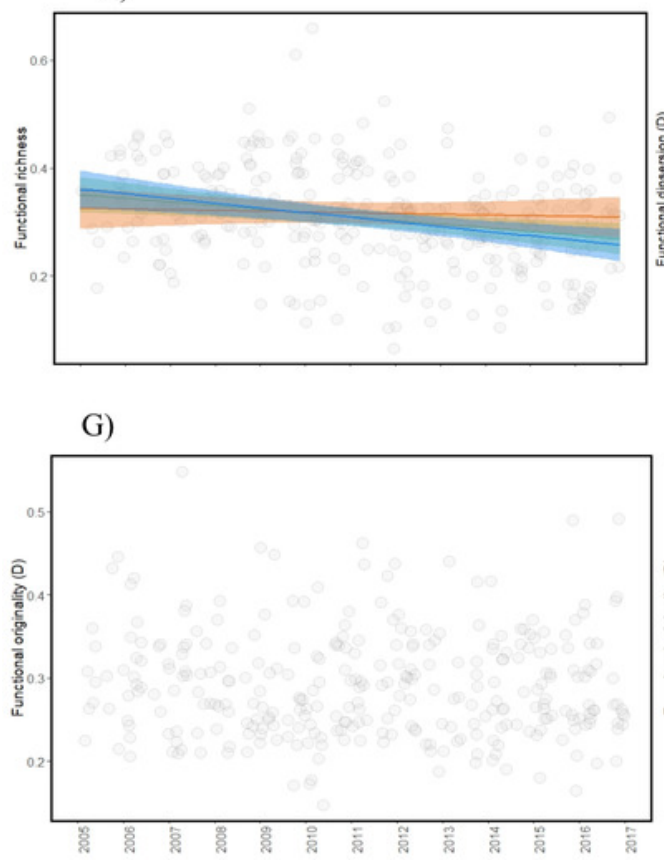

B)

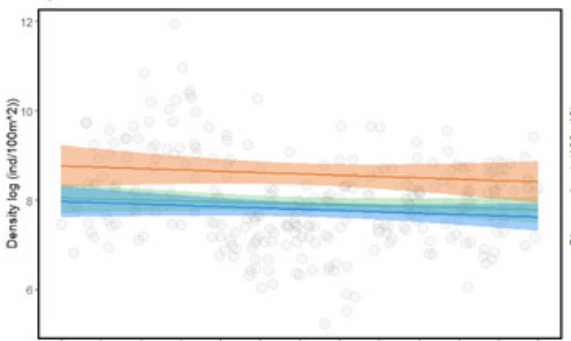

E)

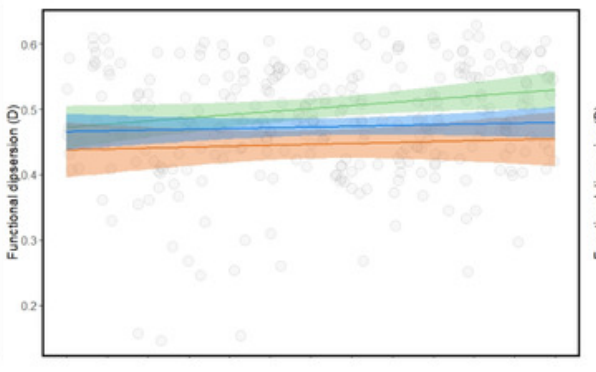

H)

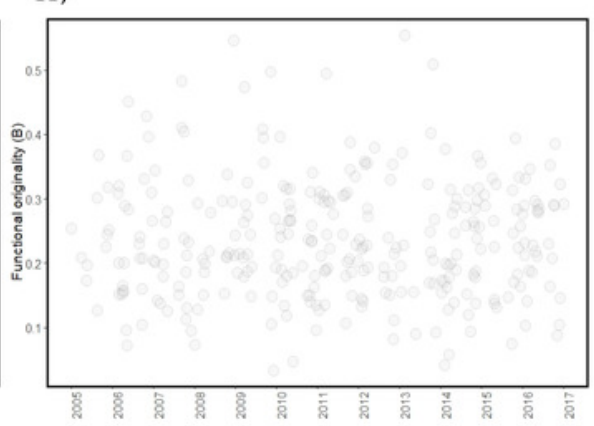

C)

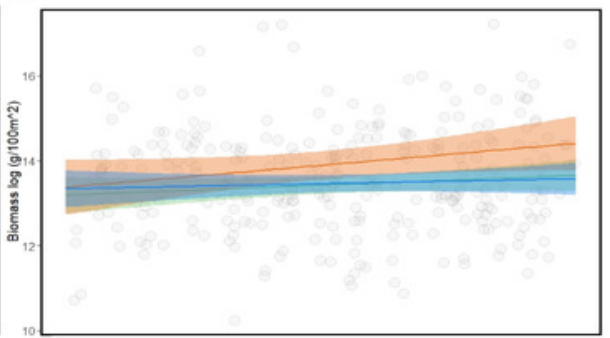

F)

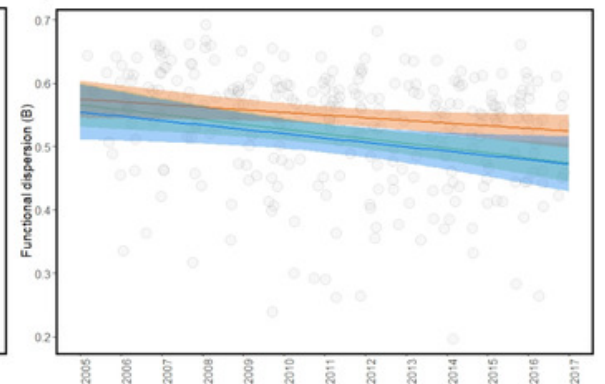

I)

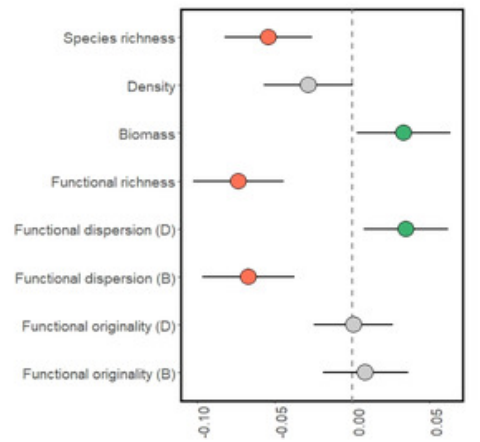




\section{Figure 5}

Figure 5. Winner and loser species over a 13-year study period in PNZMAES.

From A) to C), the winner and loser species in term of occurrence, density, and biomass. The mean coefficient estimates ( $\pm 95 \%$ confidence interval) of the GLMMs show the effect of the year on the common species (present in at least $50 \%$ of the transects). Only the parameters of the species for which a significant effect was found, and for which the models were validated, are shown. Green and red circles indicate significant positive and negative values, respectively. The position in the functional space of winner and loser species is shown in the functional space for the occurrence $(D, G)$, density $(E, H)$, and biomass $(F, I)$. The size of the dots is proportional to the z-values of the models. For the density and biomass functional spaces, the average-weight centroids (one per transect) are indicated by blue and purple dots, respectively. The $95 \%$ confidence interval ellipses of the centroids values are illustrated. 


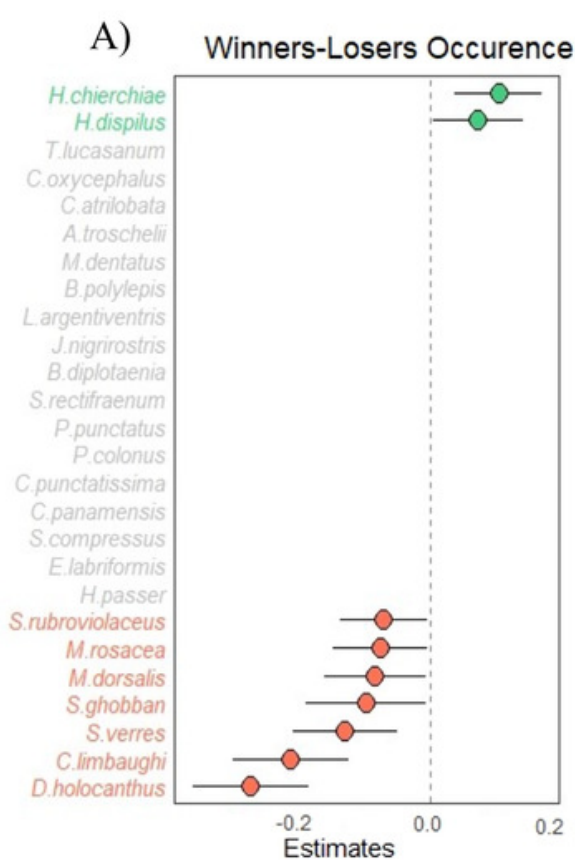

D)

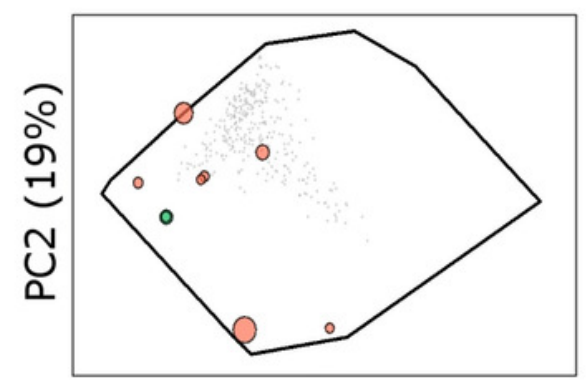

G)

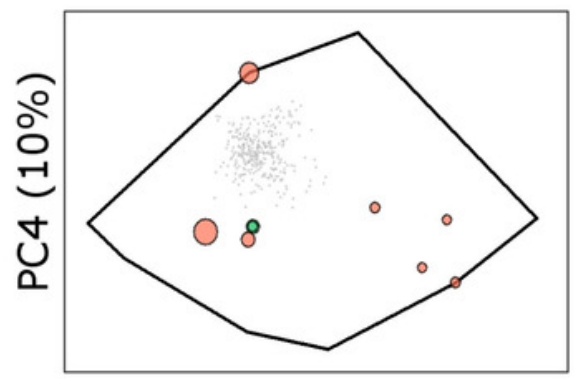

B)

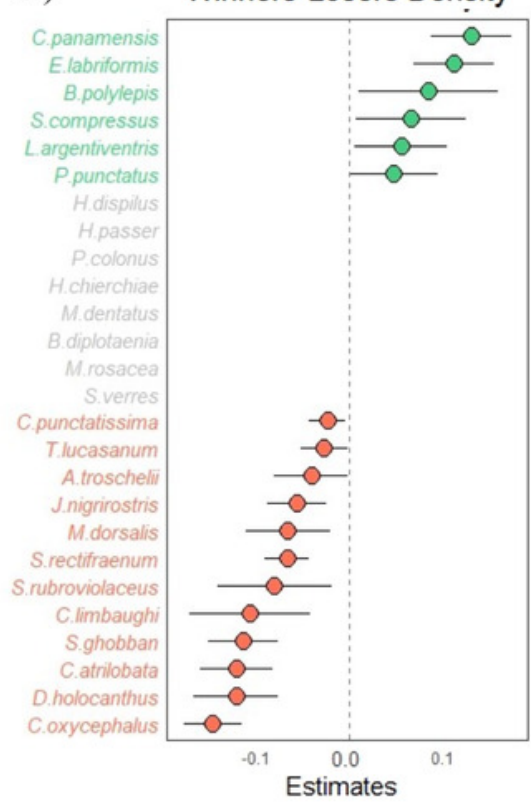

E)

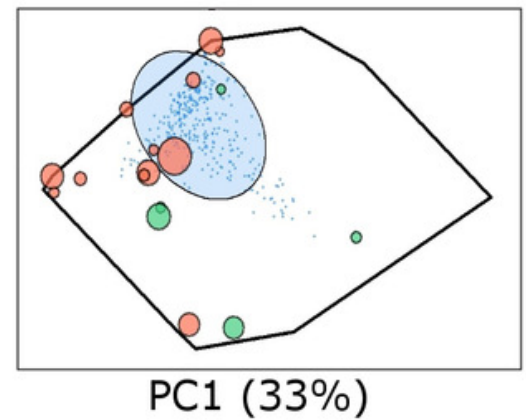

H)

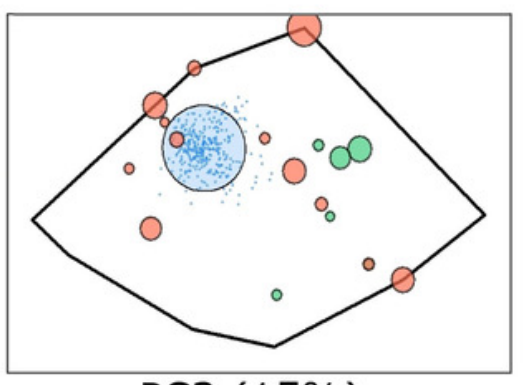

PC3 (15\%)
C) Winners-Losers Biomass

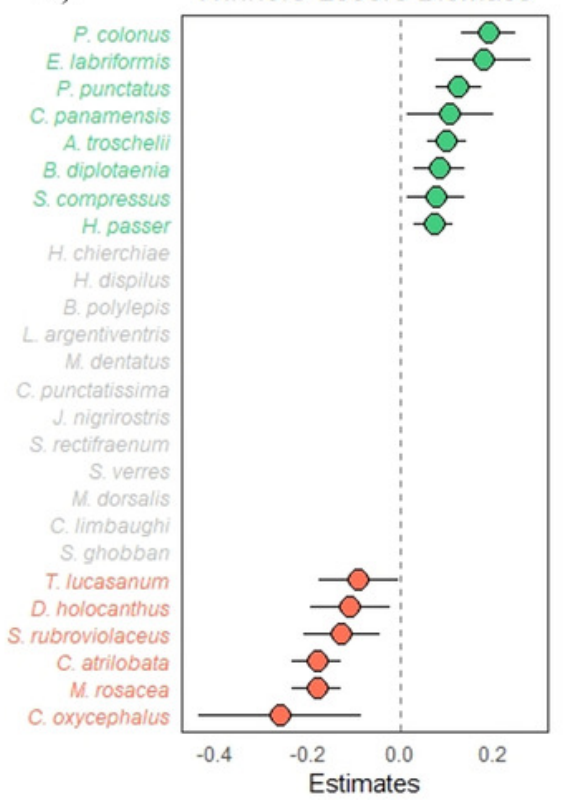

F)

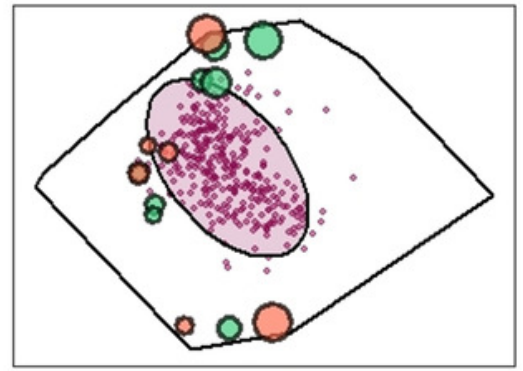

I)

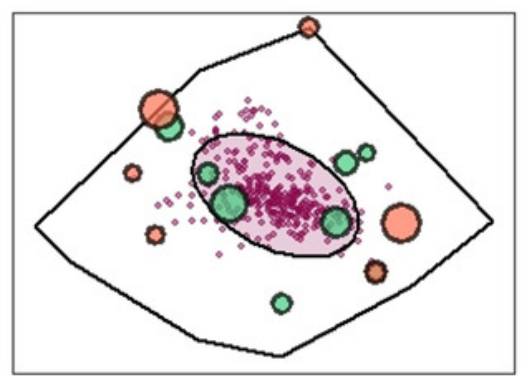

